\section{Marnie Hughes-Warrington}

History goes to the movies. Studying History on film Routledge (London/New York) 2007, 2I8 p., $£$ I5,99, І п в N 978-0-415-32828-9

Met dit boek van ruim 200 pagina's schaart de Australische historica Marnie Hughes-Warrington zich in de gelederen van filmhistorici als Marc Ferro (I977), Pierre Sorlin (I980), John O'Connor (I990) en Robert Rosenstone (2006) die zich in de afgelopen decennia intensief hebben beziggehouden met de relatie tussen film en geschiedenis. Grofweg waren 'film als bron voor het verleden' en 'film als vorm van geschiedschrijving' de belangrijkste benaderingen in hun werk. Hughes-Warrington, auteur van o.a. Fifty key thinkers on history (2000), constateert dat er ondanks de ontzaglijke stroom van publicaties over historische films sinds de jaren zeventig grote en ernstige lacunes blijven bestaan in het debat hierover. Uitgaande van de fundamentele vragen: wat is geschiedenis en waar dient geschiedenis voor? pakt ze een aantal van deze lacunes aan. Ze richt zich daarbij zowel op de invloed van nieuwe technologieën zoals DVD's, internet en digitale effecten op de productie, promotie en receptie van films over het verleden als op nieuwe, andere mogelijkheden om te achterhalen hoe in verleden en heden het publiek historische films waardeert en interpreteert.

De sterke nadruk op receptie in haar boek hangt onder andere samen met de manier waarop ze tegen de relatie tussen film en geschiedenis aankijkt: geschiedenis kan niet eenvoudigweg in historische films 'aangetroffen' worden, maar openbaart zich in de interactie tussen degenen die films maken en degenen die er naar kijken. Juist door de ontvangst van een film te onderzoeken, kunnen we volgens Hughes-Warrington antwoord geven op de fundamentele vraag: waar dient geschiedenis voor? Filmmaatschappijen houden al veel langer rekening met receptiefactoren en ontwikkelen op basis daarvan hun reclame- en marketingstrategieën. De casting van de blockbuster TITAN IC bijvoorbeeld werd voorafgegaan door uitgebreide try-out tests van het effect van Leonardo DiCaprio op een vrouwelijk publiek, en DiCaprio bleek de belangrijkste 
reden te zijn waarom vooral jonge meisjes de film meer dan een keer gingen zien. In de promotie van film speelt de filmmuziek (in dit geval de 'theme'song 'My heart will go on' gezongen door Celine Dion) een essentiële rol en wordt vaak in meerdere uitvoeringen uitgebracht om maar zo vaak mogelijk uitgezonden te worden. In deze marketing strategie past ook het op de markt brengen van een replica van de halsketting van Rose, de vrouwelijk hoofdpersoon van TITAN IC en een aankleedpop met garderobe van deze Rose. Make-up fabrikant Max Factor kwam met een reeks van zes lipstickkleuren die geïnspireerd waren op de film en kopers konden bij aankoop daarvan ook een exemplaar van het boek James Cameron's Titanic aanschaffen.

Inderdaad, zegt Hughes-Warrington, historische films verkopen goed, deels door dit soort marketingstrategieën, maar we dienen vooral te onderzoeken wat ze verkopen en hoe ze ontvangen worden want de aard en invloed van geschiedenisfilms is anders dan van een spijkerbroek of een chocoladereep. Publieksonderzoek (zowel in de jaren dertig als in de jaren negentig) heeft bijvoorbeeld aangetoond dat historische films een belangrijke rol spelen als verbindingselement tussen iemands hedendaagse leven en zijn/haar herinneringen aan vroegere ervaringen met familie, vrienden en geliefden. Door middel van de producten die rond een film op de markt gebracht worden (bijvoorbeeld naaipatronen van Titanic kostuums en bijbehorende accessoires) kunnen dergelijke herinneringen veiliggesteld worden en zij vervullen daarmee dus een belangrijke rol in het alledaagse leven van het publiek. Hugh-Warrington wijst voor deze betekenis van geschiedenisfilms ook op de talloze websites en discussiesites rond films als TITANIC. Fan-fiction - verhalen van toeschouwers die het filmverhaal veranderen en/of uitbreiden - laat volgens haar zien dat toeschouwers niet de passieve ontvangers van consumptie ideologie zijn waarvoor ze door cultuurcritici vaak gehouden werden. Deelnemers aan deze fan-fiction sites blijken vaak een eigen canon ontwikkeld te hebben met gedeelde criteria voor esthetische en historische kwaliteiten in films. Zij houden zich bezig met een creatief proces van 'remaking history', even- als de deelnemers aan games die op deze films geënt zijn. Kijkers van DVD's die van historische films uitgebracht worden zijn vaak ook niet passief - zij vergroten hun kennis en begrip van esthetische beslissingen en effecten door scenes meerdere malen en minutieus te bestuderen met behulp van verschillende afspeelsnelheden. Ook hier constateert Hughes-Warrington dat er voor geschiedenis/geschiedenisfilms een belangrijke rol in het dagelijks leven van het publiek is weggelegd.

Deze focus op het aanboren van nieuwe bronnen voor productie- en receptieonderzoek is een van de vernieuwende elementen van HughesWarringtons aanpak. Ze combineert deze waar mogelijk met tekstanalyses van talloze geschiedenisfilms en gaat daarnaast ook nog in op historische films als esthetische vormen van expressie. Bovendien wordt aan het einde van ieder van de zeven thematische hoofdstukken een poging gedaan om eerdere publicaties over de thematiek van zowel historici/historiografen als van filmwetenschappers/filmhistorici met elkaar te verenigen. Deze terugkerende paragrafen worden in het eerste, theoretische en methodologische hoofdstuk 'Words and images, images and words' ingeleid. Eén van haar uitgangspunten daarbij is dat filmhistorici een onderscheid maken tussen 'geschiedenis in beelden' en 'geschiedenis in woorden' waardoor er een kloof ontstaan is tussen wat Hayden White noemt 'historiophoty' en 'historiografie', twee vormen van geschiedschrijving die verschillend gewaardeerd worden. Hughes-Warrington stelt voor om dit onderscheid te laten vervallen en ze als gelijkwaardig te beschouwen. Hiermee sluit ze aan bij Robert Rosenstones recente pleidooi (History on film/ film on history, 2006) om films over het verleden te erkennen als een nieuwe vorm van geschiedschrijving.

Jammer genoeg heeft Hughes-Warrington gemeend haar originele idee (geschiedenis is niet eenvoudigweg in films te vinden maar in de afspraken en argumenten van degenen die die films maken en bekijken) uit te moeten werken in een onnodig complex betoog. Daarmee doet ze niet alleen een zwaar beroep op het vermogen van de lezer om de meervoudige hoofdlijnen te 
d kunnen blijven volgen, maar bovendien verN wacht ze van de lezer ook dat deze zijn/haar kenป nis van de inzichten van een breed scala aan postजे moderne denkers paraat heeft. Voeg daarbij haar

neiging om voortdurend vooruit te wijzen naar 7 hoofdstukken die nog komen moeten en haar inzet van zo'n 250 films als bewijs- en illustratiemateriaal, dan moet de aanduiding van 'helpful introductory text' op de achterkant met erg veel korrels zout genomen worden.

Tity de Vries 